\title{
Analysis of Macroeconomic Determinants of Peruvian Gold Export Value in the Period 2003-2019
}

\author{
Carlos Alberto Tovar Jaco ${ }^{1}$, Madeleyne Karol Mucha Alhuay ${ }^{1}$, Pedro Bernabe Venegas Rodriguez ${ }^{1}$, Nivardo Alonzo \\ Santillán Zapata ${ }^{1} \&$ Jimmy Alberth Deza Quispe ${ }^{1}$ \\ ${ }^{1}$ Universidad Continental, Peru \\ Correspondence: Carlos Alberto Tovar Jaco, Universidad Continental, Peru.
}

Received: September 19, 2020

Accepted: November 11, 2020

Online Published: January 11, 2021

doi:10.5430/ijfr.v12n2p43

URL: https://doi.org/10.5430/ijfr.v12n2p43

\begin{abstract}
The current research examined the macroeconomic determinants of Peruvian gold exports in the period 2003-2019 as well as their relative importance. Regressors employed were inflation, exchange rate, international rate, interest rate and Swiss gross domestic product. Ordinary Least Square along with $R^{2}$ decomposition and standardized coefficients were employed. The research found positive effects of inflation and international gold price on the dependent variable; while, Swiss gross domestic product was found to have a negative effect to Peruvian gold export. By the usage of $R^{2}$ decomposition and standardized coefficients it was found that international gold price is the most relevant regressor when explaining Peruvian gold export values.
\end{abstract}

Keywords: gold export, $\mathrm{R}^{2}$ decomposition, inflation, international gold price

\section{Introduction}

Gold is one of the most valued metals around the world. For one hand, gold is seen as a store of wealth; and in the other hand, gold is employed for electric devices and jewelry (Fabozzi et al., 2008). Then, just focusing on its value as an investment asset, gold is often seen as the least risky investment (Ahmed \& Vveinhardt, 2018). Therefore, gold investors harness gold for defending themselves from inflation, financial crisis and other externalities (Shakil et al., 2018). However, gold, as every commodity, has inherent volatility because of their dependence on international prices (Fabozzi et al., 2008). Consequently, gold price may suffer reductions on its value in the international markets impacting in both gold investors and producers.

In the global supply chain of precious metals, there is interdependence between gold producers and gold "users" ( $\mathrm{PwC}, 2019)$. In that relationship, Peru is a world class gold supplier. This country has been known in every part of its history by having huge resources of this mineral. Pre-inca civilizations and the Incas Empire were famous for extracting gold and employing it as jewelry or ceremonial purposes (Petersen \& Brooks, 2010). Under the Spanish domination, the extractions of metals, especially gold and silver, and delivering them to Spain were the core of the economy (Chocano et al., 2010). Nowadays, mining continues to be the Peruvian economy main activity (Ernst and Young, 2019), and its most attractive sector (Ernst and Young, 2019).

Hence, Peru is the major gold producer in Latin America and the sixth in the world (Ministerio de Energia y Minas, 2018). In consequence, gold represents about $17.2 \%$ of total Peruvian trade exchange in FOB values (Ministerio de Energia y Minas, 2018). Moreover, Peru has the highest proven reserves of that mineral in Latin America and it is the fifth in the world (Ministerio de Energia y Minas, 2018). Then, gold production has big potential of growth. As a prove of this; currently, there are almost 59 mining projects, 7 related to gold, valued in more than 52 billon of dollars (Cámara de Comercio de Lima, 2019). It is not surprising, then, that gold is a big player in the Peruvian economy (Zevallos et al., 2017).

Consequently, given the huge importance of gold to the Peruvian economy both in present and future; it would be necessary to understand the external dynamics of Peruvian gold exports. Scilicet, the question the current analysis aims to answer would be to know which macroeconomic factors could impact in the Peruvian exports of gold. Although it can be though that gold exports changings could impact only in mining companies, gold-made devices manufacturers, and gold investors; due to the huge significance of gold exports in the Peruvian economy the impact could affect almost every one. Then, Peruvian economic actors should be aware of the gold exports behavior. 
Consequently, the current research will analyze the effects of selected macroeconomic factors in the Peruvian gold export performance.

\section{Literature Review}

Studies about the impact of certain macroeconomic factors on country exportations were carried around the world. Islam et al. (2019) analyzed the relationship between exports with selected macroeconomic determinants in Bangladesh in the period 1971-2018. Regressors employed were exchange rate, inflation rate and interest rate. Stationary and cointegration analysis were harnessed. The research found that there were positive relationships between exchange rate, inflation rate and interest rate on the dependent variable.

Todshki \& Ranjbaraki (2016) analyzed the macroeconomic determinants of Iranian steel exports in the period of 1075-2011. Stationary and cointegration analysis were employed for encountering the relationship of the gross domestic product [hereinafter gdp], global oil price, population and steel production on the dependent variable. The research findings were that there was an impact of gross national product on Iranian exports.

Hadi \& Setyo (2019) studied the factors affecting the value of export of Indonesian cocoa beans in the period 1996-2015. Regressors employed were international price of cocoa beans, exchange rate, domestic production and world gross domestic product. By employing an OLS regression they found that international cocoa beans price, cocoa bean production, and world gross domestic product had significant and positive effects on the dependent variable; while, the exchange rate had a negative effect on the dependent variable.

Nursiam \& Rahayu (2019) studied the relationship between Bangladesh exports and certain macroeconomic factors. Regressors employed were interest rate, inflation rate, broad money, and exchange rate and Quantum index of industrial production. Analyzed data belonged to the period 2011-2016. Stationary and cointegration analysis were performed. Unfortunately, no relationship between the dependent variable and its regressors were found.

Javed et al. (2020) aimed to analyze the Pakistani basmati exports levels and its relationship with macroeconomic factors. Both Pakistani and its 11 principal trading partner's exchange rate and inflation rate data were employed as regressors in the period 2011-2016. By using Park's Feasible Generalized Least Square the research found that the Pakistani exchange rate had a negative impact on basmati exports; while its partners' exchange rate had a positive effect on the dependent variable. Similarly, Pakistani exchange rate had a negative relationship on the basmati exports while partners' inflation was found to have a positive effect.

Rahman (2017) studied the short run and long run dynamics between export performance of Bangladesh and macroeconomic variables. The period studied lasted from 2011 to 2016 and the regressors employed were interest rate, inflation rate, broad money, exchange rate, and industrial production index. The study found that in the long run there were negative effects of inflation and exchange rate on export; while, there were positive effects of interest rate, money supply and industrial production index. However, no relationship was found for any variable in the short run.

Pambudi et al. (2019) investigated the relationship of Indonesian biodiesel export and its relationship with macroeconomic factors. Selected macroeconomic regressors were Gross domestic product, exchange rate, biodiesel price and distance between Indonesia and its trading partners. Data employed belonged to the period 2012-2015 and Ordinary leas square analysis was harnessed. The research found that gross domestic product, exchange rate and biodiesel had a positive and significant effect on the dependent variable. While, distance was found to impact it negatively.

Finally Majeed \& Ahmad (2006) analyzed 11 macroeconomic determinants and their effects on 75 developing countries exports. Data was taken from World Development Indicators and the chosen period was 15 years. By using ordinary least squared regression the research found that gross domestic product, grow of gross domestic product, national savings exchange rate among others had a positive effect on the 75 counties exports level.

Therefore, studies in other world location aimed to prove the relationship of certain macroeconomic factors and the exports level of a certain product or in certain countries. However, there was not found any study that analyzed the relationship of such macroeconomic determinants on the Peruvian gold exports. Hence, the current study aims to fill that gap by studying the relationship of available macroeconomic factors on the levels of Peruvian gold exports.

\section{Theoretical Framework}

\subsection{Gold International Price}

As every commodity, gold price is not constant around the time. Fabozzi et al. (2008) claim that commodity prices are the product of the interaction of the global supply chain; hence, commodity demand countries and offering ones. Since gold is a non-renewable resource it depends more in the demand than in the offer (Fabozzi et al., 2008). Hence, 
gold price may rise as the demand of this product rise. Empirically, the relationship between the commodity international prices and the exports level of supplier countries was seen in the period called "commodity boom" which lasted from 2003 to 2010. In Peru, because of the high commodities price, its commodity exports value had a continuous growing period; while a huge reduction of its commodity trading value was followed after the reduction of commodity prices (Organismo Supervisor de la Inversión en Energía y Minería, 2017). Cuddington \& Jerrett (2008) call such cycles as commodity supercyles.

\subsection{Inflation}

The most common definition of inflation is the average increasing of good prices through time (Blanchar et al., 2012). Moreover, inflation, according to Borodin \& Strokov (2011), is a determinant in the Central Bank decision of determining the interest rate. Inflation impact on exports levels have been widely discussed with mixed results. Empirically, Lovasy (1962) showed that in countries with moderate levels of inflation, exports levels increased more than in the "stable" countries; however, in countries with high inflation levels, exports fell.

\subsection{Exchange Rate}

The exchange rate is the expression of the national currency in a foreign currency. In the Peruvian economy, the exchange rate environment is called a one of dirty float since there are times in which the Central Bank can intervene. It is common, also, that both exports and imports are declared in a foreign currency, which is United States Dollars or US\$, to Peruvian trading authorities. Theoretically, exchange rate has a negative relationship with export levels; then devaluation should increase exports while an appreciation should affect negatively export levels. However, empirically such relationship is not always followed (Kemal \& Qadir, 2005).

\subsection{Trade Partner GDP}

It is the gross national product of the main trade partner of the product studied origin country. According to Trade Map database, Switzerland is the principal trade partner of Peruvian gold exports; hence, about one of third of Peruvian gold exports is destined to Switzerland. Therefore, the Swiss gdp variation is going to be taken as a regressor. Empirically, Pambudi et al. (2019) found a positive relationship between the trading partner gdp and the origin country export levels.

\subsection{Ordinary Least Squares}

An ordinary least square model is expressed as follows:

$$
y=\beta_{0}+\beta_{1} x_{1}+\cdots+\beta_{k} x_{k}+u
$$

Where $y, x_{1}, x_{2} \ldots x_{k}$ are the observed random scalars; $\mathrm{u}$ is the error or unobservable random disturbance; and $\beta_{0}+\beta_{1}+\beta_{2} \ldots \beta_{k}$ are the constants or parameters that are going to be estimated (Woolridge, 2010).

Burton (2020) states that every OLS regression should fulfill the following assumptions:

First of all, linearity. This condition asks for the model independent variables to share individually and collectively a linear relationship with the dependent variable (Burton, 2020). This assumption can be checked both graphically and statistically. Statistically, the F test is employed.

Moreover, regressors should be independent of each other. This assumption means that independent regressors error terms are not correlated (Burton, 2020). Statistically, Durbin-Watson test can be employed in order to check the meeting of this assumption.

Also, residuals must be allocated following a normal distribution. (Fonti, 2017) claims that normality distribution assumption is a precondition for every parametric statistical analysis. Moreover, Fox in Burton, (2020) states that not-normal distributed errors make estimators less efficient, affect the least squares interpretation, and dichotomization in data.

Furthermore, the dependent variable variance should be constant around the regression error variance (Burton, 2020). Hence, no constant error variance or heteroscedasticity reduces the efficiency of the OLS estimator and miscalculate the coefficient standard errors (Yang et al., 2019).

Finally, regressors should not share an almost perfect relationship, which is also called multicollinearity (Burton, 2020). Undesirable effects of the no meeting of this assumption are that OLS values are not stable and it becomes difficult to establish correctly the effects of each regressor (Burton, 2020). By the employment of Variance Inflation Factor analysis such condition was tested. 


\subsection{Decomposition of the Coefficient of Determination}

According to Huettner \& Sunder (2011) coefficient of determination $\left[R^{2}\right]$ decomposition needs the application of the theory of cooperative games with utility transfer (Huettner \& Sunder, 2011). Hence, $K=\{1, \ldots, \mathrm{j} \ldots, \mathrm{k}\}$ is the universe of the regressors or players, and grouped at once in $\mathcal{G}=\{\mathrm{G} 1, \ldots, \mathrm{Gl}, \ldots \mathrm{G} \Upsilon\}$. Hence:

$$
y=\underbrace{\beta_{0}+\beta_{I} x_{1, i}}_{G_{I}}+\ldots+\underbrace{\beta_{j} x_{j}+\ldots}_{G_{\ell}}+\ldots+\underbrace{\beta_{k} x_{k}+\ldots .}_{G_{\Upsilon}}+\alpha_{i}+\mu_{i t}
$$

$R^{2}(K)$ is the payment, the overall coefficient of determination, to be distributed for all players or regressors. For such purpose it is necessary to use the cooperative game with utility transfer known as coalition structure [CS game structure] Huettner \& Sunder (2011). Therefore, $R^{2}: 2^{K} \rightarrow \mathbb{R}, R^{2}(\varnothing)=0$, where $2^{K}$ express the strength of $K$, and the coalition structure $\mathcal{G}$ (Huettner \& Sunder, 2011).

Also it is necessary to give to each game the vector $\varphi$, for obtaining the sum of the individual values, i.e $\sum_{j \in G l} \varphi_{j}=$ $\mathrm{K}, R^{2}$, G, (Huettner \& Sunder, 2011). The external game, i.e. $K, R^{2}, \mathcal{G}$, induces the game among coalition groups; then written as $\left(K, R_{\mathcal{G}}^{2}\right)$. It assigns each group, ' $\Upsilon \subseteq \mathcal{G}$, values by $R_{\mathcal{G}}^{2}\left({ }^{\prime} \Upsilon\right)=R^{2}\left(\cup_{G_{l \in} \Upsilon} G_{l}\right)$., $R_{\mathcal{G}}^{2}\left({ }^{\prime} \Upsilon\right)$ is the $R^{2}$ value obtained from the $O L S$. Hence:

$$
\mathrm{Y}=\beta_{0}+\sum_{G_{l}} \sum_{j \epsilon G_{l}} \beta_{j} x_{j}+\varepsilon
$$

\subsection{Shapley's and Owen's Values}

Serrano (2007) claims that Shapley's values distribute payments to players in a collaborative game with utility transfer. As a complement, Owen's value makes possible the payment for the coalitions (Casajus, 2009).

Owen's value could be applied in two ways being the first one via permutation (Huettner \& Sunder 2011). It is only possible if each group's member is contiguously appearing in the permutation without any other player in between. In that case:

$$
O w_{j}\left(K, R^{2}, G\right)=\frac{1}{|\Pi(K, G)|} \sum_{\pi \in \Pi(K, G)} R^{2}\left(P_{J}^{\pi}\right)-R^{2}\left(P_{J}^{\pi} \backslash\{j\}\right)
$$

The second way happens in two events. The first one is if all regressors belong to one group. In that case:

$$
\operatorname{Sh}_{j}\left(G_{l}, r^{2}\right)=\operatorname{Sh}_{j}\left(K, R^{2}\right)
$$

However, if regressors are grouped in different groups, then each group can be treated as a variable (Huettner \& Sunder, 2011). In consequence, it is going to be necessary to distribute payments in $G_{l}$ group using the Shapley values i.e. $S h_{G_{l}}\left(\mathcal{G}, R^{2}\right)$. Therefore, the payoffs of the regressors of a particular group sum up to the Shapley value from their group external game (Huettner \& Sunder, 2011). Consequently:

$$
\sum_{j \in G_{l}} O w_{j}\left(K, R^{2}, \mathcal{G}\right)=S h_{G_{l}}\left(\mathcal{G}, R_{\mathcal{G}}^{2}\right)
$$

3.8 Data

Data employed was obtained via Banco Central de Reserva del Peru and World Bank databases. Period studied was 2003-2019.

\section{Methodology}

The current research used a descriptive, quantitative and longitudinal methodology to analyze macroeconomic factors affecting the Peruvian gold exports from 2003 to 2019, and their relative importance. All statistical analysis employed STATA software.

Ordinary Least Squared regression was employed. Therefore, it was necessary to fulfill the stationary requirement and the assumptions depicted in the theoretical framework. First, as suggested by Baumöhl \& Lyócsa (2009), variables should follow stationary behavior for avoiding spurious regressions. Then, Philip Perron test was employed for the longitudinal data. Stationary analysis results are shown in Table 2. Then, independence assumption was analyzed by employing the Durbin-Watson test as depicted in Table 3.

Next, normal distribution condition was tested. By employing the skewness/kurtosis test of the residuals, it was verified that normal distribution of residuals is satisfied as seen in Table 4. Furthermore, non-multicollinearity examination was performed by the usage of the VIF test as shown in Table 5. 
For avoiding heteroscedasticity issues robust standard errors values were employed as suggested by Stock \& Watson (2008). Moreover, linear assumption was tested via F-test. Both robust standard errors and F-test is depicted in Table 10.

Additionally, it is mandatory to check misspecification originated because of correlated errors with the regressors, and then avoiding the omitted variable bias (Long \& Trivedi 1992). For such purpose, Ramsey Regression Equation Specification Error Test was performed as shown in Table 6.

Finally, regressors' relative importance analysis was executed by the decomposition of the coefficient of determination, $R^{2}$, of every independent variable as suggested by Huettner \& Sunder (2011). Furthermore, via the multiplication of individual and $R^{2}$, and overall $R^{2}$ it was feasible to get the direct effect of each variable on the dependent variable as shown in Table 11.

\section{Results}

Table 1. Analyzed variables

\begin{tabular}{ll}
\hline Dependent variable & Macroeconomics variables \\
\hline \multirow{3}{*}{ Gold exportations } & Exchange rate \\
\cline { 2 - 2 } & International price \\
\cline { 2 - 2 } & Interest rate \\
\cline { 2 - 2 } & Inflation \\
& Swiss gdp \\
\hline
\end{tabular}

Table 1 shows the dependent variable and its regressors which are exchange rate, international gold price, interest rate, inflation and Swiss gross domestic product.

Table 2. Philip perron test

\begin{tabular}{|c|c|c|c|c|c|c|}
\hline \multirow{2}{*}{ Variable } & \multirow{2}{*}{\multicolumn{2}{|c|}{ Test statistic }} & \multicolumn{4}{|c|}{ Interpolated Dickey-Fuller } \\
\hline & & & $1 \%$ critical value & $5 \%$ critical value & $10 \%$ critical value & $\mathrm{p}$ \\
\hline \multirow{2}{*}{ Gold export** } & Z (rho) & -11.108 & -17.200 & -12.500 & -10.200 & \multirow{2}{*}{0.021} \\
\hline & $\mathrm{Z}(\mathrm{t})$ & -3.182 & -3.750 & -3.000 & -2.630 & \\
\hline \multirow{2}{*}{ Inflation } & $\mathrm{Z}$ (rho) & -14.189 & -17.200 & -12.500 & -10.200 & \multirow{2}{*}{0.004} \\
\hline & $\mathrm{Z}(\mathrm{t})$ & -4.333 & -3.750 & -3.000 & -2.630 & \\
\hline \multirow{2}{*}{ Exchange rate ${ }^{* *}$} & Z (rho) & -17.366 & -17.200 & -12.500 & -10.200 & \multirow{2}{*}{0.000} \\
\hline & $\mathrm{Z}(\mathrm{t})$ & -5.281 & -3.750 & -3.000 & -2.630 & \\
\hline \multirow{2}{*}{ Gold price** } & Z (rho) & -12.384 & -17.200 & -12.500 & -10.200 & \multirow{2}{*}{0.016} \\
\hline & $\mathrm{Z}(\mathrm{t})$ & -3.279 & -3.750 & -3.000 & -2.630 & \\
\hline \multirow{2}{*}{ Interest rate* } & $\mathrm{Z}$ (rho) & -16.374 & -17.200 & -12.500 & -10.200 & \multirow{2}{*}{0.000} \\
\hline & $\mathrm{Z}(\mathrm{t})$ & -6.856 & -3.750 & -3.000 & -2.630 & \\
\hline \multirow{2}{*}{ Swiss gdp } & $\mathrm{Z}$ (rho) & -15.791 & -17.200 & -12.500 & -10.200 & \multirow{2}{*}{0.021} \\
\hline & $\mathrm{Z}(\mathrm{t})$ & -3.890 & -3.750 & -3.000 & -2.630 & \\
\hline
\end{tabular}

*at first difference

**at second difference

Table 2 depicts that inflation and Swiss gdp were stationary at level. Moreover, interest rate was stationary at first difference. Meanwhile, gold export, exchange rate and gold international price were stationary at second difference. 
Table 3. Durbin Watson test

\begin{tabular}{lll}
\hline Statistic & Lower bound & Upper bound \\
\hline 2.34 & 0.39 & 1.967 \\
\hline
\end{tabular}

As depicted in Table 3, statistic value was higher than the upper bound; then, it was not possible to reject the null hypothesis of non-autocorrelated errors. Hence, the assumption of independence was met.

Table 4. Distribution test

\begin{tabular}{llll}
\hline Skewness & Kurtosis & Chi $^{2}$ & $\mathrm{p}$ \\
\hline 0.1757 & 0.5489 & 2.54 & 0.2811 \\
\hline
\end{tabular}

Table 4 displays that residuals were found to be normally distributed since its $\mathrm{p}$ value is greater than .05 .

Table 5. Multicollinearity test

\begin{tabular}{lll}
\hline Variable & VIF & $1 / \mathrm{VIF}$ \\
\hline Inflation & 2.610 & 0.383 \\
\hline Exchange rate & 1.900 & 0.526 \\
\hline International price & 1.560 & 0.642 \\
\hline Interest rate & 1.370 & 0.732 \\
\hline Swiss gdp & 1.330 & 0.750 \\
\hline Mean & 1.750 & \\
\hline
\end{tabular}

Table 5 gave evidence that the model did not have multicollinearity issues since the VIF values were lower than 10.

Table 6. Specification test

\begin{tabular}{ll}
\hline Statistic & $\mathrm{p}$ \\
\hline 0.73 & 0.5714 \\
\hline
\end{tabular}

Table 6 shows the specification test results. Since p value was higher than .05 , then there was evidence to claim that the model was correctly specified. Hence, omitted variable bias was avoided.

\subsection{Descriptive Statistics}

Table 7. Variables descriptive statistics

\begin{tabular}{lllllll}
\hline & Gold export* & Inflation** & $\begin{array}{l}\text { Exchange } \\
\text { rate** }\end{array}$ & $\begin{array}{l}\text { International } \\
\text { price*** }\end{array}$ & $\begin{array}{l}\text { Interest } \\
\text { rate** }\end{array}$ & $\begin{array}{l}\text { Swiss } \\
\text { gdp** }\end{array}$ \\
\hline Mean & 6546.843 & 2.827 & 3.103 & 1049.885 & 19.132 & 1.912 \\
\hline Median & 6790.950 & 2.649 & 3.186 & 1224.200 & 18.861 & 1.900 \\
\hline Max & 10745.500 & 6.650 & 3.479 & 1668.060 & 25.357 & 4.100 \\
\hline Min & 2101.640 & 0.245 & 2.638 & 363.623 & 14.085 & -2.200 \\
\hline Standard deviation & 2605.630 & 1.543 & 0.272 & 414.184 & 3.589 & 1.511 \\
\hline Variation coefficient & 0.398 & 0.546 & 0.088 & 0.395 & 0.188 & 0.790 \\
\hline
\end{tabular}

*expressed in millions of US\$

** Percentage

$* * *$ US\$ per troy pounds 


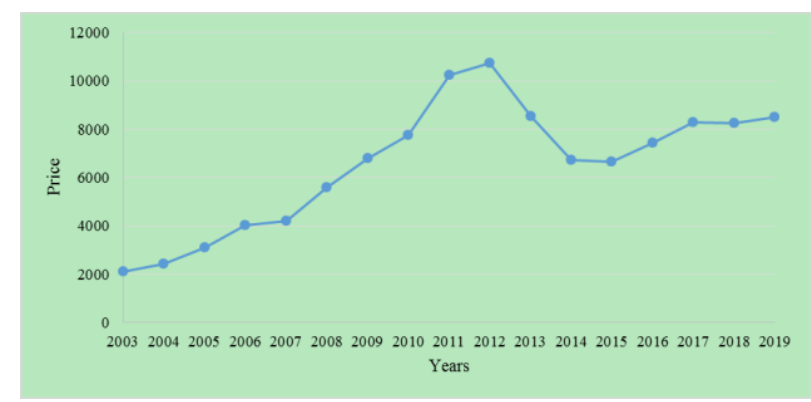

Figure 1. Peruvian gold exports

Figure 1 depicts the behavior of Peruvian gold export from 2003 to 2019 expressed in its average FOB value. It is noticeable a continuous increasing of the value from 2003 to 2012 which coincides with the end of the period called "commodity boom". After that year, the value fell until 2014 and it has been recovering since that year though not recovering its 2012 FOB values. Table 7 shows that the median of the value was 6546 million of dollars, the peak value reached in 2012 was 10745 million of dollars; and its lowest value was the one registered in the beginning.

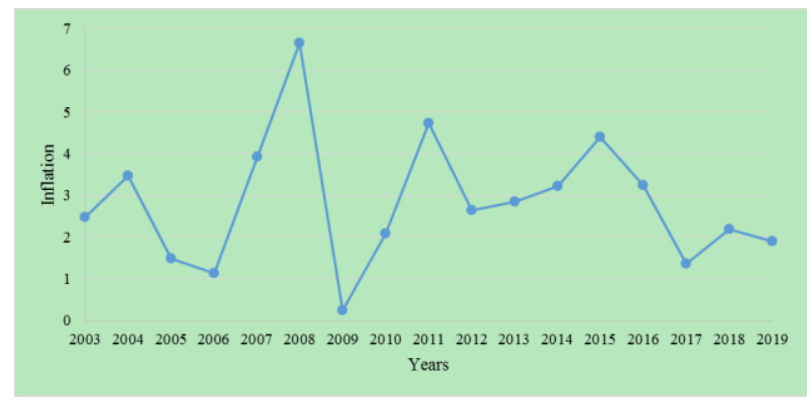

Figure 2. Inflation

Figure 1 shows the inflation evolution in the 2003-2019 periods. The figure shows a cyclical behavior of inflation with growing periods such as 2003-2004, 2006-2008, 2009-2011, 2012-2015 and 2017-2018. Table 7 shows that the highest inflation value, .6650, was reached in 2008 and immediately fell until meeting its lowest value in 2009 . That value was .245. In average the inflation value was 2.827 .

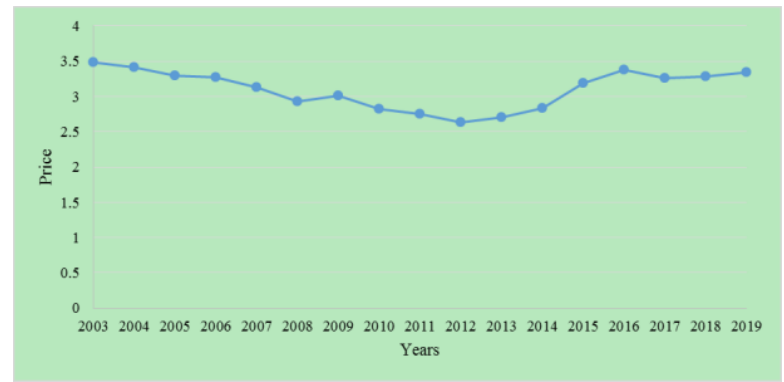

Figure 3. Exchange rate

Figure 3 depict the exchange rate behavior in the studied period. It can be seen that the exchange rate continuously fell from 2003 to 2012 with a little growth in 2009. From 2012 to 2019 the exchange rate grew every year with the exception of 2016. In average, the 2019 exchange rate level did not meet the initial levels but it is expected for that to happen in the next years. Table 7 provides that the maximum exchange rate value was 3.479 and its lowest value was 
2.638. Those values were reached in 2003 and 2012 respectively. Finally, in the period studies the average value was 3.103.

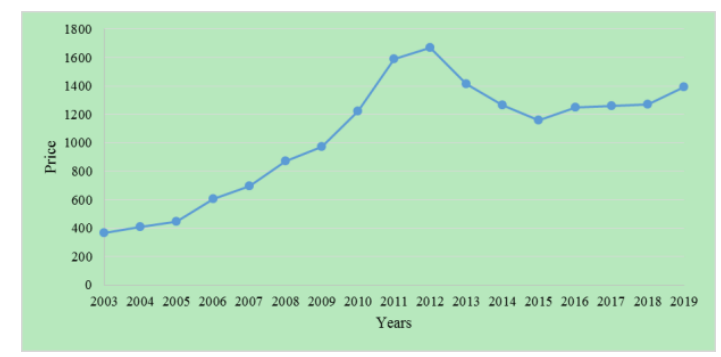

Figure 4. Gold international price

In the period 2003-2019, as depicted in Figure 4, gold international price had a continuous growth from 2003 to 2012, followed with a deep fall until 2015, and a recovery until 2019. Table 7 depicts that the international price highest value was US\$ 1668.060, reached in 2012; and the lowest value, met in 2015, was US\$ 363.623. Graphically, the international gold price has a similar behavior with Figure 1, i.e. Peruvian gold export.

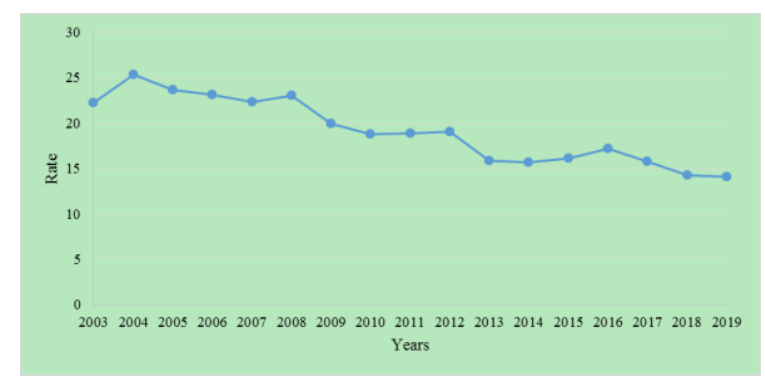

Figure 5. Interest rate

Figure 5 portrays the Peruvian interest rate from 2003 to 2019. In a general view it can be seen that the Peruvian interest rate had a decreasing behavior from 2004 to 2019 though some increasing periods. Also, it is noticeable that the highest interest rate year was 2004; while the lowest one was 2019. Table 7 shows that the highest interest rate value was $25.357 \%$ and the lowest $14.085 \%$.

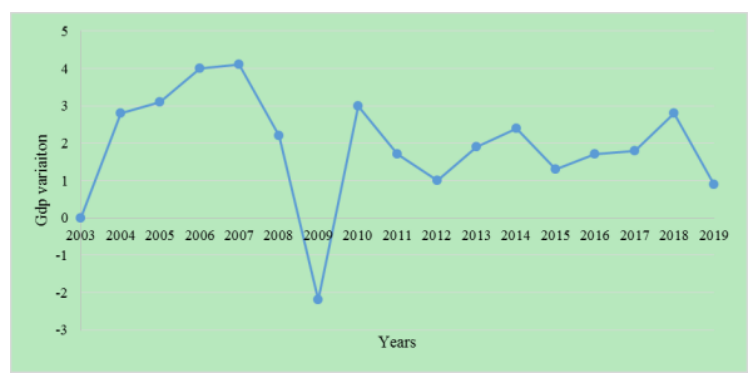

Figure 6. Swiss GDP

Figure 6 depicts the gross domestic product of the principal destination of Peruvian gold export, Switzerland, through the 2003-2019 periods. Swiss gdp had a cyclical behavior with growing periods like the 2003-2007, 2009-2010, 2012-2014, and 2015-2018. The deepest falling period happened in 2009 when the Swiss gdp had a 
$-2.2 \%$ contraction; while its peak was reached in 2007 with an expansion of $4.1 \%$ as stated in Table 7 . In average the Swiss economy had a $1.9 \%$ expansion.

\subsection{Regression and Relative Importance Analysis}

Table 8. Regression analysis

\begin{tabular}{|c|c|c|c|c|c|c|c|}
\hline Gold export & Coefficient & $\begin{array}{l}\text { Standardized } \\
\text { coefficients }\end{array}$ & $\begin{array}{l}\text { Robust Standard } \\
\text { Error }\end{array}$ & $\mathrm{t}$ & $\mathrm{P}>\mathrm{t}$ & $\begin{array}{l}\text { Confidence } \\
95 \%\end{array}$ & Intervals \\
\hline Inflation* & 184.272 & 0.248 & 91.738 & 2.010 & 0.075 & -23.254 & 391.798 \\
\hline Exchange rate & 400.541 & 0.057 & 1675.008 & 0.240 & 0.816 & -3388.591 & 4189.673 \\
\hline International price $* * *$ & 6.211 & 0.783 & 1.261 & 4.930 & 0.001 & 3.359 & 9.063 \\
\hline Interest rate & 74.658 & 0.078 & 208.362 & 0.360 & 0.728 & -396.689 & 546.004 \\
\hline Swiss gdp* & -187.840 & -0.233 & 99.189 & -1.890 & 0.091 & -412.222 & 36.542 \\
\hline Constant & -130.601 & $-7.15 \mathrm{E}-10$ & 487.970 & -0.270 & 0.795 & -1234.466 & 973.264 \\
\hline $\mathrm{F}$ & 8.520 & & & & 0.003 & & \\
\hline $\mathrm{R}^{2}$ & 0.768 & & & & & & \\
\hline
\end{tabular}

Table 9. Decomposition analysis

\begin{tabular}{|c|c|c|c|}
\hline Gold export & Overall $\mathrm{R}^{2} \%$ & Individual \% & Individual $\mathrm{R}^{2} \%$ \\
\hline Inflation & & 8.857 & 6.893 \\
\hline Exchange rate & & 0.989 & 0.769 \\
\hline International price & 77.830 & 65.773 & 51.191 \\
\hline Interest rate & & 21.211 & 16.508 \\
\hline Swiss gdp & & 3.171 & 2.468 \\
\hline
\end{tabular}

Table 8 exhibits that inflation, exchange rate, international price, and interested rate seemed to have a positive relationship with gold export; while, interest rate and Swiss gdp appeared to have a negative effect on gold export. However, only inflation, international price and Swiss gdp relationships to gold export proved to be statistically significant. Standardized coefficients show that the most important variable by its weight was gold international price whiles the lowest exchange rate.

According to table 9, the coefficient of determination $\left[R^{2}\right]$ for the entire model was .768; hence it is possible to claim that the regressors were able to explain $76.8 \%$ of the dependent variable effects. After decomposing $R^{2}$, it is noticeable that about $65.773 \%$, which was the highest one, of the whole $R^{2}$ value was attributed to gold international price. The second highest contribution, 21.211\%, was made by interest rate. Both inflation and Swiss gdp contributed to the whole $R^{2}$ in $8.857 \%$ and $3.171 \%$ respectively. The lowest contribution to coefficient of determination was done by exchange rate $[0.989 \%]$.

Furthermore, when multiplying individual $\%$ by overall $R^{2}$, Table 9 depicts that, among statistically significant regressors, international gold price by itself was able to explain $51.191 \%$ of the dependent variable behavior, inflation explained $6.893 \%$, and Swiss gdp $3.171 \%$. Although not being statistically significant, interest rate was responsible of $16.508 \%$ of the dependent variable variance.

In consequence, statistical significance along with standardized coefficients, and decomposition analysis gave evidence for stating that the most important regressor for Peruvian gold export is the international price of gold. Also, that regressor with inflation and Swiss gdp provide about $60.552 \%$ of the Peruvian gold export variance. 
Finally, the obtained $\mathrm{F}$ value in Table 8 was 8.520 , with a p-value of .003; hence, it was possible to claim the model was acceptable and meets linearity assumption.

\section{Discussion}

The current research aimed to understand the factors that could impact in the Peruvian gold exports level. Regressors such as inflation, exchange rate, international rate, interest rate and Swiss gdp were studied. The research found that gold international prices and inflation had a positive effect on Peruvian gold export; while Swiss gdp had a negative effect. Moreover, along with the $R^{2}$ decomposition, it was shown that international gold price explained by itself more than a half of the dependent variable behavior. Then, it can be stated that the most important regressor for Peruvian gold export is international gold price. Also, it is important to add that statistically significant regressors provide about $60.552 \%$ of the effects of the dependent variable.

The significant positive effect of international price on export levels is similar to the findings of Pambudi et al., (2019) who found that international biodiesel prices had a positive effect on Indonesia biodiesel exports. Moreover, Hadi \& Setyo (2019) found that international prices of cocoa beans had a positive relationship with this product exports. Although it is true that none of the mentioned studies analyzed gold specifically, both of them proved that international prices had a positive effect on a raw material exportation level.

Furthermore, the current research encountered that inflation had a positive effect on gold export. Although, this finding did not match with the theoretical proposal, similar results were found by Islam et al. (2019). They encountered that inflation of trading partners had a positive effect on export level, but inflation of the exporter country had a negative one. However, Rahman (2017) found that inflation had a negative effect on export in the Bangladesh market in the long run.

Moreover, the research found that the main partner gdp, i.e. Switzerland had a negative effect on Peruvian gold export. This outcome matched with the results of Pambudi et al., (2019) in the Indonesian market, and Hadi \& Setyo (2019) in their study of cocoa beans exports. Both of them found that their partner gross domestic product had a positive relationship with the exports.

Finally, no significant relationships were found between exchange rate and interest rate, and the dependent variable. Rahman (2017) also did not find any relationship for the aforementioned regressors in the short run. In the case of exchange rate, Javed et al. (2020), Pambudi et al., (2019), Islam et al. (2019), and Majeed \& Ahmad (2006) encountered a positive relationship of exchange rate in export; while Hadi \& Setyo (2019), and Rahman (2017) [in the long run] found a negative effect of exchange rate on the dependent variable. For interest rate, Rahman (2017) [in the long run] encountered a positive relationship on export as well as Islam et al. (2019).

\section{Conclusions}

The current research aimed to identify and explain the macroeconomic regressors with the capability of affecting Peruvian gold exports. Hence, inflation, exchange rate, international rate, interest rate and Swiss gdp were chosen as potential explanatory factors. OLS regression was employed and its assumptions were met. Moreover, relative importance analysis was performed by the $R^{2}$ decomposition as long with employing standardized coefficients. After meeting necessary assumption for assuring the robustness of the model, it was found that international gold price and inflation had positive effects on Peruvian gold export; while, Swiss gdp had a negative one. Further analysis was made by employing $R^{2}$ decomposition as long with standardized coefficients; hence, it was proven that international gold price is the most important regressor for explaining Peruvian gold price because of its high contribution to overall $R^{2}$, and its standardized coefficient weight. Moreover, when joined with the other two significant regressors, their $R^{2}$ is about $60.552 \%$.

In that way, it is possible to state that gold Peruvian export rely in a highly in international gold price. It also was recorded by the Peruvian authorities whom linked the fall of Peruvian gold export to the end of the "commodity boom". Hence, after that period, Peruvian gold export fell deeply, but it has been growing since 2015. Although, the theory states that inflation has a negative relationship with the exports. The research found that inflation had a positive effect in Peruvian gold exports. Hence, it is possible to claim that probably inflation carried devaluation on the Peruvian currency, then favoring the exports though no significant relationship was found for exchange rate.

Moreover, it is interesting to add that although interest rate did not have statistical significance in its positive relationship with Peruvian gold export, this regressor contributed in about $16.5 \%$ which may indicate that this regressor should not be sub estimated. 
Furthermore, the principal trade partner gdp for Peruvian gold exports, i.e. Switzerland, had a negative impact on Peruvian exports. Hence, a possible explanation for this phenomenon is that under recession periods, swiss investors may be moved to protect their money by buying gold since gold is seen as a safe haven (Shakil et al., 2018). Consequently, when Swiss economy faces problems, Swiss people and institutions increase their demand for Peruvian gold.

Hence, it is expected that under situations of economic crisis, Peruvian gold export values grow.

\section{References}

Ahmed, R. R., \& Vveinhardt, J. (2018). Estimation of causal relationship between world gold prices and KSE 100 index: Evidence from Johansen cointegration technique. Acta Oeconomica, 68(1), 51-77. https://doi.org/10.1556/032.2018.68.1.3

Baumöhl, E., \& Lyócsa, S. (2009). Stationarity of time series and the problem of spurious regression. MPRA. Retrieved from https://mpra.ub.uni-muenchen.de/27926/

Blanchar, O., Amighini, A., \& Giavazzi, F. (2012). Macroeconomia (5th ed.). Pearson Educación.

Borodin, K., \& Strokov, A. (2011). Econstor (March 2019).

Burton, A. (2020). OLS (Linear) Regression. In The Encyclopedia of Research Methods and Statistical Techniques in Criminology and Criminal Justice. Wiley.

Cámara de Comercio de Lima. (2019). Informe ecoómico. La Cámara, 7-8.

Casajus, A. (2009). The shapley value, the owen value, and the veil of ignorance. International Game Theory Review, 11(4), 453-457. https://doi.org/10.1142/S0219198909002431

Chocano, M., Contreras, C., Quiroz, F., Mazzco, C., \& Flores, R. (2010). Compendio de Historia Económica del Perú III. In Compendio de Historia Económica del Perú III. https://doi.org/10.1007/s13398-014-0173-7.2

Cuddington, J. T., \& Jerrett, D. (2008). Super cycles in real metals prices?. IMF Staff Papers, 55(4), 541-565. https://doi.org/10.1057/imfsp.2008.19

Ernst and Young. (2019). Peru's mining \& metals investment guide 2019/2020. Retrieved from http://www.embajadadelperu.org.co/docs/Mining 2019 - 2020.pdf

Fabozzi, F., Fuss, R., \& Kaise, D. (2008). The handbook of commodity investing (1st ed.). John Wiley \& Sons, Ltd.

Fonti, V. (2017). Feature Selection using LASSO. VU Amsterdam, 1-26. https://doi.org/10.1109/ACCESS.2017.2696365

Hadi, A. F., \& Setyo, W. A. (2019). Analysis of factors affecting the value of export of indonesian cocoa beans in 1996-2015. Ekuilibrium: Jurnal Ilmiah Bidang Ilmu Ekonomi, $14(1), \quad 16$. https://doi.org/10.24269/ekuilibrium.v14i1.1509

Huettner, F., \& Sunder, M. (2011). Working Paper, No. 100 Frank Hüttner / Marco Sunder Decomposing R2 with the Owen value Oktober 2011 Decomposing with the Owen value. In Working Paper, Issue 100. Retrieved from http://www.marco-sunder.de/stata/rego.html

Islam, S., Sahajalal, M., \& Alim, A. (2019). The Impact of Macroeconomic Factors on Exports Earnings in Bangladesh: 1971-The Impact of Macroeconomic Factors on Exports Earnings in Bangladesh: 1971-2018. International Journal of Scientific Research in Multidisciplinary Studies, 5(August), 62-65.

Javed, I., Rehman, A., Nabi, I., Razzaq, A., Saqib, R., Bakhsh, A., ... Luqman, M. (2020). Performance and macroeconomic determinants of basmati rice exports from pakistan. Sarhad Journal of Agriculture, 36(2), 617-624. https://doi.org/10.17582/JOURNAL.SJA/2020/36.2.617.624

Kemal, M. A., \& Qadir, U. (2005). Real exchange rate, exports, and imports movements: A trivariate analysis. Pakistan Development Review, 44(2), 177-195. https://doi.org/10.30541/v44i2pp.177-195

Long, J. S., \& Trivedi, P. K. (1992). Some specification tests for the linear regression model. Sociological Methods \& Research, 21(2), 161-204. https://doi.org/10.1177/0049124192021002003

Lovasy, G. (1962). Inflation and exports in primary producing countries. Staff Papers (International Monetary Fund), 9(1), 37-69. https://doi.org/10.2307/3866081

Majeed, M. T., \& Ahmad, E. (2006). Determinants of exports in developing countries. Pakistan Development Review, 45(4), 1265-1276. https://doi.org/10.30541/v45i4iipp.1265-1276 
Ministerio de Energia y Minas. (2018). Anuario Minero 2018. https://doi.org/10.30875/ee10314e-es

Nursiam, N., \& Rahayu, V. S. (2019). The effect of company size, sales growth, Current Ratio (Cr), Net Profit Margin (Npm) and Return on Equity (Roe) on Stock Prices. Manajemen Bisnis, 9(1), 13-21. https://doi.org/10.22219/jmb.v9i1.9433

Organismo Supervisor de la Inversión en Energía y Minería. (2017). La industria de la minería en el Perú - 20 años de contribución al crecimiento y desarrollo económico del país. Retrieved from http://www.osinergmin.gob.pe/seccion/centro_documental/mineria/Documentos/Publicaciones/Osinergmin-Ind ustria-Mineria-Peru-20anios.pdf

Pambudi, A., Puspitawati, E., \& Nursechafia, N. (2019). The determinants of biodiesel export in Indonesia. Signifikan: Jurnal Ilmu Ekonomi, 8(2), 207-216. https://doi.org/10.15408/sjie.v8i2.10961

Petersen, G., \& Brooks, W. E. (2010). Mining and metallurgy in ancient Perú. Special Paper of the Geological Society of America. https://doi.org/10.1130/2010.2467

PwC. (2019). Mine 2019 Resourcing the future.

Rahman, F. (2017). Impact of selected macro-economic variables on the export performance of Bangladesh. IOSR Journal of Economics and Finance, 8(2), 21-27. https://doi.org/10.9790/5933-0802032127

Serrano, R. (2007). Cooperative games: core and shapley value. CEMFI Working Paper, 2007(0709), 1-22.

Shakil, M. H., Mustapha, I. M., Tasnia, M., \& Saiti, B. (2018). Is gold a hedge or a safe haven? An application of ARDL approach. Journal of Economics, Finance and Administrative Science, 23(44), 60-76. https://doi.org/10.1108/JEFAS-03-2017-0052

Stock, J. H., \& Watson, M. W. (2008). Heteroskedasticity-robust standard errors for fixed effects panel data regression. Econometrica, 76(1), 155-174. https://doi.org/10.1111/j.0012-9682.2008.00821.x

Todshki, N. E., \& Ranjbaraki, A. (2016). The impact of major macroeconomic variables on Iran's steel import and export. Procedia Economics and Finance, 36(16), 390-398. https://doi.org/10.1016/s2212-5671(16)30051-x

Yang, K., Tu, J., \& Chen, T. (2019). Homoscedasticity: An overlooked critical assumption for linear regression. General Psychiatry, 32, 1-5. https://doi.org/10.1136/gpsych-2019-100148

Zevallos, M., Villarreal, F., Del Carpio, C., \& Abbara, O. (2017). Metal prices and international market risk in the peruvian stock market. Revista Economia, 40(79), 87-104. https://doi.org/10.18800/economia.201701.003

\section{Copyrights}

Copyright for this article is retained by the author(s), with first publication rights granted to the journal.

This is an open-access article distributed under the terms and conditions of the Creative Commons Attribution license (http://creativecommons.org/licenses/by/4.0/). 